\title{
CONFLICT ON NATURE RESOURCE MANAGEMENT IN HUTOVO BLATO NATURE PARK
}

\author{
Višnja Bukvić ${ }^{1} \&$ Nikola Glamuzina ${ }^{2}$ \\ ${ }^{1}$ Sveučilište Hercegovina, Fakultet društvenih znanosti dr. Milenka Brkića, Mostar, Bosna i \\ Hercegovina (visnjabukvic@net.hr, fdzmb@hercegovina.edu.ba \\ ${ }^{2}$ Sveučilište u Splitu, Filozofski fakultet, Split, Croatia (nikola.glamuzina@ffst.hr)
}

Bukvić, V. \& Glamuzina, N.: Conflict on nature resource management in Hutovo Blato Nature Park. Nat. Croat., Vol. 29, No. 2, 267-286, 2020, Zagreb.

The paper deals with the problem of natural resource management in Hutovo Blato Nature Park Blato in Bosnia and Herzegovina. The official policy for the protection of Mediterranean wetlands has put to the forefront the problem of exploiting the abundant but limited natural resources such as water, agricultural land, fish stocks and wetland birds. A quarter of a century after the establishment of the Nature Park the problem of nature resource management is more troubled than ever before. This research aims to define the primary stakeholder groups in the area that question and challenge the official policy of nature protection and to analyse their points of view and attitudes. The stakeholder analysis relates to analysis of endangered animal species and vegetation and issues that are results of stakeholders' activities.

Key words: Hutovo Blato, wetlands, nature resource management, Nature Park, environment

Bukvić, V. \& Glamuzina, N.: Sukob oko upravljanja prirodnim vrijednostima u Parku prirode Hutovo blato. Nat. Croat., Vol. 29, No. 2, 267-286, 2020, Zagreb.

$\mathrm{U}$ radu se raspravlja o problemu upravljanja prirodnim vrijednostima The paper deals with the problem of natural resource management in Hutovo Blato Nature Park Blato in Bosnia and Herzegovina. The official policy for the protection of Mediterranean wetlands has put to the forefront the problem of exploiting the abundant but limited natural resources such as water, agricultural land, fish stocks and wetland birds. A quarter of a century after the establishment of the Nature Park the problem of nature resource management is more troubled than ever before. This research aims to define the primary stakeholder groups in the area that question and challenge the official policy of nature protection and to analyse their points of view and attitudes. The stakeholder analysis relates to analysis of endangered animal species and vegetation and issues that are results of stakeholders' activities.

Ključne riječi: Hutovo blato, močvare, upravljanje prirodnim vrijednostima, Park prirode, okoliš

\section{INTRODUCTION}

Hutovo Blato (Fig. 1) is a part of the Neretva river delta which consists of two parts - Upper and Lower Delta. It is an area of Mediterranean wetlands that is characterised by an abundance of fishes and birds. While the Upper Delta is inside the borders of the Republic of Bosnia and Herzegovina, the Lower Delta is a part of the Republic of 


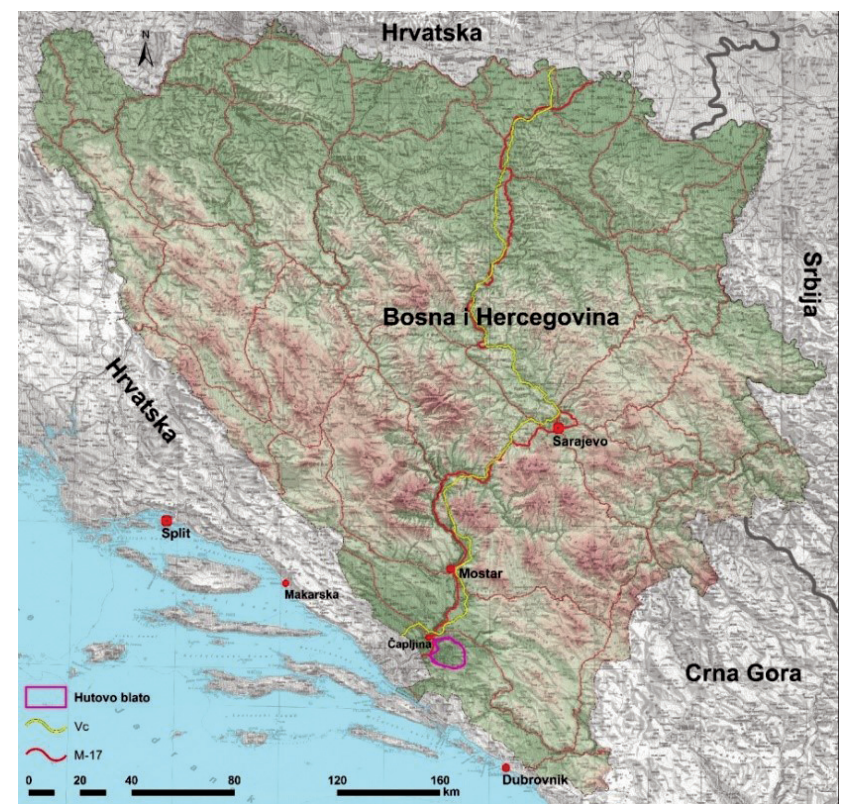

Fig. 1. The position of Hutovo blato Nature Park in relation to the main roads

Croatia*. The most attractive section of the Upper Delta is the wetlands area called Hutovo Blato, situated on the left bank of Neretva, underneath the karstic hills.

The landscape of Hutovo Blato is defined by wetlands that are a result of water flowing from the higher karstic terrain to the east. The poorly developed soil of the karstic fringe determines the absence of surface watercourses. Water from precipitation accordingly is filtered through the karstic underground and fills depressions inside Hutovo Blato, forming lakes and wetlands. Excessive water from lakes and wetlands is taken to the Neretva by the nine kilometre long Krupa River.

Because of the variety of wetland birds Hutovo Blato has attracted hunters from the surrounding areas throughout history. Fowling continued even after 1954 when the ornithological reserve was established. Comprising a total area of $61.44 \mathrm{~km}^{2}$ the reserve stayed open for wildfowling except for the special reserve Štrka (established five years later with area of just $3.5 \mathrm{~km}^{2}$ ) that was closed for shooting, fishing and any kind of commercial activities. In decades to come the reserve was put on the list of wetlands of international importance (in 1971) and became part of international project for Mediterranean wetlands protection (in 1980). The nature protection policy was furthermore upgraded by the establishment of a Nature Park in 1995, which played a crucial role in ending the hunting and wildfowling (in 2000). At the turn of the century Hutovo Blato got further international recognition by BirdLife International conservation organisation (inclusion on the list of wetlands of international importance in 1998) and

\footnotetext{
* The international borderline almost totally corresponds with the natural border of the Upper and the Lower Delta. Only a small portion of the Lower Delta is inside the territory of Bosnia and Herzegovina.
} 
by UNESCO (listed as a wetland of international importance in 2001 according to the Ramsar convention).

By establishing a Nature Park, environmentalists achieved an important goal in introducing a policy of effective nature conservation. On the other hand, problems of nature resource management came to light since different stakeholder groups started to question the very policy of nature protection and conservation. Such an attitude is a result of conflicts of views regarding the exploitation of local nature resources and of contrary approaches towards the policy of nature conservation.

The conflict among different stakeholder groups around nature resources in Hutovo Blato has not previously been researched scientifically. This paper aims to cover that aspect of local resource management from the scientific point of view. It is based on research conducted by a biologist and a geographer. As well as defining the stakeholder groups that challenge the policy of nature protection, the main goals of the research are to produce an analysis of the stakeholders' attitudes towards the nature protection policy, analysis of the segments of everyday life and the local economy that are affected by nature protection as well as an analysis of the biological resources that are affected by stakeholder activities. In addition, the researchers will propose possible solutions for the current situation based on international experiences.

\section{OVERVIEW OF SCIENTIFIC RESEARCH}

Conflicts among various social groups over the issues of nature resource management, as a result of nature protection policy, have attracted the attention of scientists for decades. The traditional concept of nature protection is based on a top-down command-and-control approach that did not take into consideration the needs and attitudes of local populations towards such a policy. That is the main reason this kind of concept proved to be ineffective in many cases around the world.

As a response to such a situation, new approaches towards the problem of involvement of different groups of local populations were devised. The widely used scientific concept is based on analysis of such groups that are understood as stakeholders in the process of nature resource management. Stakeholder analysis (SA) relies on researching into their views, attitudes and needs for nature resources that come into conflict with the policy of nature protection and conservation. The very analysis enables us to obtain a knowledge that gives us a deeper understanding of the conflict and an adequate tool for proposing solutions. One of them is a participatory model that involves stakeholders in nature resource management. It is often suggested as a model that increases the sustainability and adaptability of a nature conservation policy (Evely et al., 2011).

The complexity of nature resource management in wetlands attracts researchers around the world and there have been many papers on the subject in recent years. In many of them the importance of local population in nature resource management is especially analysed from the theoretical point of view (Frooman, 1999; Guijt, 1999; Fajber, 2005; Рrobst \& Hagmann, 2005; Vernooy et al., 2005; Buijs et al., 2012; AgrawAL, 2014; Reed et al., 2014; AttLee et al., 2015).

The stakeholder analysis methodology is widely used in contemporary research not just when dealing with nature resource management but also in other cases, such as the application of infrastructure planning (ENSERINK, 2000), economic (SAvAGE et al., 1991; Mitchell et al., 1997) and even health policy (VARvasovszKy \& Brugha, 2000). 
The impact of various social groups on nature protection policy as well as the question of the implementation of a participatory management model are analysed in case studies from different parts of the world - from Africa (Adekola \& Mitchell, 2011; German et al., 2012a, 2012b; Cullen et al., 2014; Dixon \& CARrie, 2016; Marambanyika \& Beckedahl, 2016; Nsengimana et al., 2017; Peter et al., 2018), Asia (Wattage \& Mardle, 2005; Verma \& Negandhi, 2011; Qiu et al., 2014; Zheng et al., 2014; Cohen-Shacham, 2015; Everard et al., 2019; MaAn \& Chaudhry, 2019) all the way to Europe (Prell et al., 2009; Aggestam, 2014; Nastran, 2014; De Vente et al., 2016; Hulshof \& Vos, 2016; Pristupa et al., 2018; Reed et al., 2018), Australia (Pendred et al., 2016; Sмith et al., 2016) and North America (VAISSIÈre, 2017).

The different repercussions of effective biological protection for local populations in protected marine areas of Southeast Asia are especially educative (CHRISTIE, 2004). In addition, importance of the wetland wildlife from the perspective of the visitors is also an issue that should not be overlooked (Folmer et al., 2013).

The question of the political framework inside which issues of nature resource management take place is unavoidable. Such problems are also researched from different points of view including the theoretical question of decentralisation and democratic representation in the process of managing natural resources (TANUI et al., 2012; RIвот, 2016). On the other hand, many researchers point out that the very theory of participation of stakeholders just like public engagement in environmental management depends on the political framework and institutions (REeD et al., 2018). Especially informative are researches that assess stakeholders' influence on spatial planning in a protected area (Lovrić et al., 2011) or stakeholders' involvement in nature resource management (MAGYERA \& GENSKOW, 2013). Part of the political framework is the issue of hunting and fishing regulations and the biological management of animal resources such as migratory birds and fish (Montoya \& Mesón García, 1999).

The climatic fluctuations of the contemporary period are increasingly important for wetland ecosystems around the world. The influence of climate change on the Mediterranean wetland's ecosystems (FATORIć et al., 2014) is a fresh topic that also can be applied to Hutovo Blato wetland to some extent. The socio-environmental problems resulting from climate changes in the Simiyu wetlands in Tanzania (HAmisi et al., 2012), although involving a tropical part of the world, are also informative.

The problem of invasions of non-indigenous fish species has been analysed recently in the wetlands of west India (Ajmal Hussan et al., 2019). Changes of fish species distribution as a result of human activities in Hutovo Blato have been analysed recently (TuTMAN et al., 2012). Heavy metal distribution in fish tissues in six fish species in Hutovo Blato Nature Park has also been investigated. The study shows a high concentration of some metals in inner organs and gills of some species as a result of intensive agricultural activities in the neighbouring area (HAs-ScHön et al., 2008).

The problem of water resource management due to global climate change and irresponsible human behaviour has also been subject of many papers. Such a situation has recently been analysed in case of Lake Braccio in Italy (Armenia et al., 2019), Greek islands (Kourtis et al., 2019) and the wetlands of West India (NAsKar et al., 2017).

\section{METHODOLOGICAL APPROACH}

During extensive previous researches in Hutovo Blato Nature Park Blato the authors of this paper became aware of the problem of the rapid deterioration of the wetland environment. This situation has also been periodically covered in the media primarily 
from the point of view of the Nature Park administration. The authors found a need to address that problem from a scientific perspective and such an opinion was additionally fortified by preliminary interviews with the Nature Park administration and a certain member of the local population.

The main objective of the research is getting a deeper knowledge and understanding of the conflict over nature resource management in the Nature Park by defining the stakeholders involved and their relations with the deterioration and degradation of the wetlands.

The ongoing conflict regarding the nature resource management in Hutovo Blato Nature Park Blato is researched applying the stakeholder analysis methodology. The very term "stakeholder" has been understood differently in scientific literature and has been changing over the decades (REeD \& Curzon, 2015). For the purpose of this paper we understand it to be any individual or a group who can influence or is influenced by nature resource management policy. The identification of stakeholders was based on the authors' knowledge of the Hutovo Blato from previous researches, an analysis of media coverage of issues and conflicts in the Nature Park and of the first part of semi-structured interviews that were conducted by the authors among the local population, Nature Park administration and other parties involved. The interviews consisted of a questionnaire divided into four parts with open-ended questions covering all areas of the nature protection policy in the Nature Park. The first part was based on general questions of stakeholders' knowledge of nature protection policy and their viewpoints of the current state of nature resource management in Hutovo Blato.

After identifying the stakeholders, the next step was to establish a division between them based on relevant scientific literature: between those who affect or determine a decision or an action and those who are affected by the same action (in both positive and negative senses). The first group of stakeholders may be called active and the latter passive. It is important to have in mind that sometimes the distinction between the two groups is not easy to establish since one stakeholder may be involved in nature resource management in both active and passive ways at the same time (GRIMBLE \& WeLlARD, 1997). Such a distinction was made by questions from the second part of the interview that dealt with aspects of life of the interviewees that are affected by the nature protection policy and their involvement and roles in the decision-making process.

After defining the stakeholders and their positions in the nature resource management process the actual stakeholder groups were also analysed from the point of view of distinction between notions of conflict and trade-off. Conflict is understood as competition or disagreement between stakeholder groups about nature resource management. Trade-off is a dispute around the same issue inside a stakeholder group (GRIMBLE, 1998). Both conflicts and trade-offs were defined by the third part of the interview that was focused on interviewees' viewpoints regarding the specific issues of nature resource management.

The recognition of stakeholders, conflicts and trade-offs has its purpose in defining and proposing a solution in cases of inadequate or inefficient nature protection policy. The public engagement of stakeholders is described with the term participation- the process of the involvement of stakeholders and the public in nature resource management (REED et al., 2018). The question of possible participation in nature resource management and nature protection policy was covered by the fourth part of the interviews about the decision-making process: what the stakeholders would change about it and 
the current managing tools. Based on that, the authors of this paper have proposed a model of participation that could alleviate current conflict(s) and make nature protection in Nature Park policy more effective (Fig. 2). On the ground of the current knowledge about the nature resource management in Hutovo Blato this research will evaluate the validity of three hypotheses.
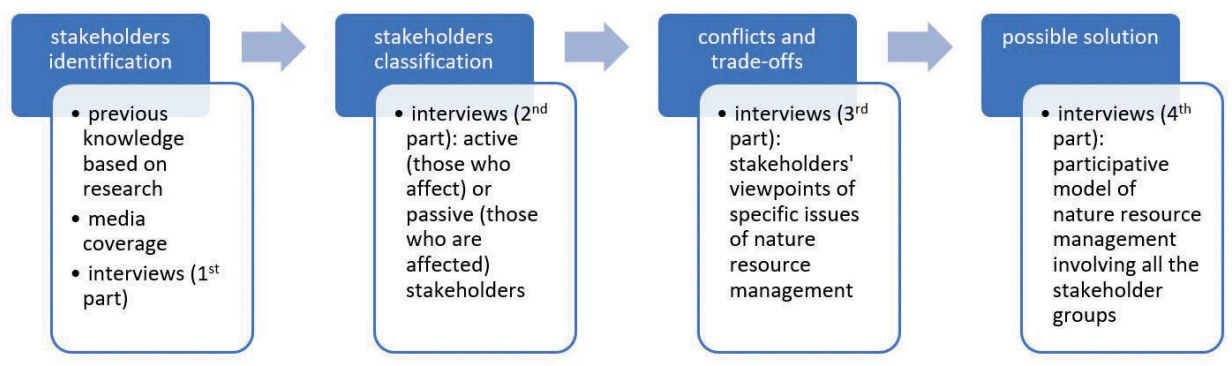

Fig. 2. Methodological approach: the research phases

The first one says that inadequate water resource management by the local hydropower plant presents the biggest threat to the nature protection and conservation policy in Hutovo Blato. The second hypothesis claims that beside the hydropower sector there are other less visible stakeholder groups that equally challenge nature protection and conservation policies. And finally, we will evaluate the third hypothesis that asserts that the current positions of stakeholder groups can be coordinated with a more comprehensive and better designed nature protection policy.

\section{RESULTS}

The wetlands of Hutovo Blato are an interdependent and interwoven environmental system with economic and social importance and dimensions. The interviews provided us with an insight into the dimensions and they helped us understand historical aspect of the conflict. Until the second half of the $20^{\text {th }}$ century, the wetlands supported the basic needs of local population, primarily with food (fowling, fishing), water and firewood. At the same time small parcels of arable land were used for farming and cattle grazing. The nature system was dependent on an influx of fresh water from the surrounding area by filtration through karstic terrain. The Mediterranean climate (together with sub-Mediterranean variation deeper inland) determines the water distribution during a year that is dependent of rainfalls. There is a humid season during the colder months (from October to March) and a dry season during the warm and hot months (April to September). While periodical floods during the humid season were constant problem for local population, there were no water shortages in the wetlands during the dry season.

The natural balance in the wetlands started to change in the second part of the $20^{\text {th }}$ century with the construction of the pumped-storage hydropower plant in 1979. It was constructed at the edge of the village of Svitava at the eastern outskirts of Hutovo Blato. For purpose of the plant the reservoir of Svitavsko jezero (Svitava Lake) was made by flooding a part of the wetlands. On the other hand, some parts of the wetlands were deprived of the same quantities of fresh water. The situation is the most critical 
in the area of Deransko jezero (Derane Lake) just next to Svitava Lake, which goes almost totally dry during the summer months. Such a situation was not so visible in the 1980s, but it deteriorated at the turn of the centuries partially due to climate changes that are characterized by the interchange of extremely dry with extremely humid years. The establishment of the Nature Park in 1995 signified the start of conflict over the nature resource management that culminated in 2015 when the federal ministry in charge of nature protection withdrew the working licence of the hydropower plant because of excessive exploitation of water that endangers the natural balance and life of birds and fish in the Park ${ }^{* *}$.

Just by analysing the media reports and from authors' previous research in Hutovo Blato it was possible to detect two stakeholders involved in the nature resource management dispute: the administration of the Nature Park on one hand and the hydropower plant officials on the other. The interviews that the authors conducted among the inhabitants of settlements inside the Nature Park and at the outskirts of the official borders showed that there are three more stakeholder groups: local population, hunters, and renters of apartments.

In relation with the decision-making process it is possible to distinguish the active stakeholders (decision makers) from passive stakeholders who are affected by the current decision-making process. The two active stakeholders are the Nature Park administration and the hydropower plant management. Both have institutional mechanisms and legislative powers that enable them to influence the nature protection and conservation process. Their actions have direct consequences on the environment of the Nature Park in short term and long-term senses.

They are also able to determine and direct current and future policies regarding the exploitation of natural resources in Hutovo Blato.

The three remaining stakeholder groups (locals, hunters, renters) consist of a wide range of individuals that are unified by the same or similar goals. They are not as compact as the active stakeholders since they are characterized by internal disputes (trade-offs) regarding nature resource management. They are also more interrelated and interwoven than the active stakeholders. What they have in common is their relation to the policy making: they are primarily affected by the nature protection policy and therefore can be called passive stakeholders. Their informal internal structure, except for hunters who are more institutionalized but not too powerful (and therefore may be considered passive and active at the same time), makes their actions less consequential and influential.

The interviews showed that there is also a fine line dividing the notion stakeholder from that of stakeholder group. Our research showed that the three passive stakeholders -locals, hunters, renters - can be easily called stakeholder groups since they consist of many individuals and associations. On the other hand, the active stakeholders - the Nature Park administration and hydropower plant management - are more structured from the organizational point of view although they are also formed by more than one unit. The Nature Park administration is backed by their colleagues from the nature protection institutions and also by environmentalists and scientists. On the other hand, the hydropower plant management is backed by colleagues from the electricity supply

\footnotetext{
** The plant's management responded with a lawsuit and the case is still in process.
} 
sector and the regional and national government who view the electricity supply as a crucial economic sector important for exports.

As expected, the interests and agendas of the five stakeholders are diverse (Tab. 1). The two active stakeholders - Nature Park administration and hydropower plant management - are very determined in their views on nature resource management. While the Park officials are trying to implement the official laws and diminish the negative human impact on the environment, the plant management is resolute to continue water exploitation for electricity production. The other three stakeholders that can be labelled passive are also gathered around their own agendas, however in a much more informal and loose way than the active stakeholders.

Tab. 1. Stakeholders, their activities and environmental effects in Nature Park Hutovo blato

\begin{tabular}{|l|l|l|}
\hline STAKEHOLDERS & ACTIVITIES & EFFECTS \\
\hline $\begin{array}{l}\text { Nature Park } \\
\text { administration }\end{array}$ & nature protection & $\begin{array}{l}\text { positive: nature preservation } \\
\text { negative: conflict with traditional activities }\end{array}$ \\
\hline $\begin{array}{l}\text { Hydropower } \\
\text { sector }\end{array}$ & $\begin{array}{l}\text { water resources } \\
\text { exploitation }\end{array}$ & $\begin{array}{l}\text { positive: none } \\
\text { negative: wetlands destruction }\end{array}$ \\
\hline Hunters/fishermen & hunting/fishing & $\begin{array}{l}\text { positive: none in wetlands, feeding of wild animals and } \\
\text { maintenance of hunting grounds in surrounding area } \\
\text { negative: hunting without monitoring, poaching }\end{array}$ \\
\hline Tourism sector & renting & $\begin{array}{l}\text { positive: eco-products, interest in sustainable park } \\
\text { development and benefit for the local community } \\
\text { negative: wastewater, garbage dumps, wildfires, poaching }\end{array}$ \\
\hline hunting, fishing & $\begin{array}{l}\text { positive: popularisation of Nature Park, environment } \\
\text { protection support } \\
\text { negative: } \text { underdeveloped environmental awareness, waste } \\
\text { disposal, harvesting protected plant species, picking } \\
\text { medicinal herbs }\end{array}$ \\
\hline
\end{tabular}

The interviews helped to define stakeholders and their activities. However, the effects of their activities, both positive and negative, were defined by the authors during the research since stakeholders tended to enlarge the positive effects of their activities and diminish the negative ones. On the other hand, each stakeholder involved in the process generally does not show any understanding for the views of other stakeholders. There are two exceptions: first is the Nature Park administration who is aware of the need for cooperation with other stakeholders and the second is the tourism sector (renters) who understand that only true functioning of nature protection will attract more guests in the area. The same could be said only partially for the local population since inside their group there are extremely contrary views: on one hand there are those who are interested in the benefits of nature protection for the local community while on the other hand are those who oppose any kind of restrictions introduced by nature protection policy. Nevertheless, both sections of the local community have the same negative effect on the wetlands that they are not aware of since their view of the environment is deeply rooted in traditional concept of nature: it is something that has unlimited resources and that's how it's always been.

The interviews have also shown that, apart from the Nature Park officials, the stakeholders have only a very basic knowledge of the concepts of biodiversity, sustainable 
development and official nature protection policy. The same may be said of their view of the exploitation of nature resources: they see it as something static and unchanging that should be freely used by humans for their needs. Environmental, biological, ecological, educational and aesthetic values of the wetlands are something very secondary to them. Even a part of the local population that is willing to accept the implementation of nature protection policy and the tourism sector (renters) do not differ significantly from such a point of view. The sole reason of their willingness to accept the nature protection policy is motivated by the economic benefits.

\section{DISCUSSION}

While the interviews helped the authors to define the stakeholders and their attitudes toward the nature protection policy, some questions remained unanswered. Is the conflict over nature resource management recent, dating back from the year that the Nature Park was established (i.e. 1995)? Has the conflict really been introduced from the outside i.e. from the decision-makers outside of the region? And finally, what is at stake after all?

These questions appeared every time that the issue of implementation of the nature protection policy was addressed. For a better understanding of the problem and to be able to answer the questions, the authors found it necessary to introduce the time dimension. Therefore, the stakeholders were presented from the point of historical context - the way that they appeared, from the oldest to the newest. The reason for such an approach lies in the fact that although the conflict is recent, the very problem of implementation of the nature protection policy is much older.

Let us start this section of the paper with the assertion that from the point of a view of biologists (especially those specialised in ornithology, ichthyology, entomology or herpetology), geographers or other nature or Earth scientists, Hutovo Blato is an area of exceptional values. That is the starting point from which the authors will closely discuss the conflict respecting all the stakeholders involved.

\section{Hunters as the first stakeholder}

The very history of Hutovo Blato is deeply connected fowling. This unique complex of Mediterranean wetlands was, and still is, an ideal habitat for migratory birds. With the end of WWII Hutovo Blato was declared an elite hunting area that preserved its status even after the ornithological reserve was established in 1954. The first signs of limiting this form of hunting came in 1959 when a part of ornithological reserve was declared a special reserve. Under the name of the geographical location of Štrka the special reserve comprised less than $6 \%$ of the ornithological reserve. Its importance lies in the fact that it was the first time in history that a part of the wetlands in Hutovo Blato was closed for hunting, fishing and any kind of commercial activities.

Limitations did not especially bother the shooting clubs since their activities continued without any attention being paid to the borders of the special reserve. The ineffective protection was exacerbated by there being too few inspectors, low fines and inadequate regulations that could not stop poaching or enforce the laws. The scale of legal hunting was high since members of hunting clubs from Bosnia and Herzegovina and other parts of the Yugoslavian federation were regular visitors of the area. Bird hunting took place without any kind of monitoring or involvement of relevant scientists. The 
number of bird species dropped from 235 (in 1979) to 163 (in 2000) ${ }^{* * *}$. Hunting activities dropped sharply in the first part of the 1990s because of political unrest in Yugoslavia that culminated in the violent break-up. The establishment of the Nature Park in March of 1995, seven months before the signing of the peace treaty that ended the war in Bosnia and Herzegovina, did not signify the end of fowling since it continued in a sporting-recreational sense for the next five years. The jurisdiction over nature resource management was assigned to the Nature Park - and this is what hunting clubs cannot accept, still questioning its validity.

Such a view implicitly denies that there is any negative environmental influence of hunting on the bird stocks. Many members and representatives of hunting clubs do not understand the meaning of hunting bans or the concept of protecting without time limitations. Such an attitude is a source of conflict. Since hunters are institutionally organised in the form of different clubs, they use them as an institutional frame through which they try to influence decisions of the nature resource management on local, regional and national levels.

\section{Local population as the second stakeholder}

Unlike the hunters the reaction of most of the local population on the establishing of the Nature Park came with certain delay. Unaware and partially even uninterested in the new regulations, they continued with their activities. Some of their activities soon came into conflict with the nature protection policy. Among them are hunting and fishing which the locals used to practice outside of formal membership in a hunting or a fishing club and which were regarded as a tradition or part of the lifestyle. Very often such activities were practised in the form of poaching but were tolerated by the law enforcers. Local people also used small parcels of arable land for agriculture and small pastures for cattle grazing.

The fact is that agricultural activities, unlike hunting and fishing, do not have a significant environmental impact. Even though some locals even use water from local water flows when irrigating plants during dry summer months, there are no effects on the wetlands that give cause for concern. There are much bigger problems with wastewater, garbage dumps and wildfires. Wastewater from many houses inside the borders of the Nature Park is still disposed into peripheral parts of the wetlands that are flowing into the Neretva River. Illegal garbage dumps in the wetlands are currently an enormous problem especially because of the high proportions of plastic materials. Torching of the wetlands in late winter is an environmentally devastating custom with terrifying effect on birds.

The local population is concentrated inside 13 settlements with a total of 7261 inhabitants according to the 2013 census (Tab. 2). Compared to the previous census from 1991 the number of inhabitants is $7.9 \%$ smaller, only a small decline. Such a demographic trend is dictated by 11 settlements that are situated at the outskirts of the Park, outside its official borders (Fig. 3). On the other hand, there are only two settlements deep inside the borders of the Park (Prebilovci and Svitava) with just 305 inhabitants according to the most recent census. These two settlements have extremely negative population trends since the number of inhabitants in the same period decreased by almost $40 \%$. Such an undesirable demographic trend at the same time means that there has been no additional pressure from the local population on natural resources in the last 22 years.

\footnotetext{
*** It is still unclear who is more to blame for that: the flooding of the wetlands by the hydropower plant or uncontrolled and excessive hunting. The combination of both factors also should not be ruled out.
} 
Tab. 2. Number of inhabitants in settlements in the Hutovo blato Nature Park area in 1991 and 2013

\begin{tabular}{|l|c|c|c|}
\hline SETTLEMENT & Inhabitants in 1991 & Inhabitants in 2013 & INDEX (2013/1991) \\
\hline Bajovci & 181 & 135 & 74,6 \\
\hline Bjelojevići & 325 & 231 & 71,1 \\
\hline Čeljevo & 1058 & 1362 & 128,7 \\
\hline Dračevo & 630 & 621 & 98,6 \\
\hline Gnjilišta & 345 & 345 & 100,0 \\
\hline Klepci & 417 & 166 & 39,8 \\
\hline Kruševo & 300 & 242 & 80,7 \\
\hline Opličići & 1386 & 1344 & 97,0 \\
\hline Prebilovci & 174 & 61 & 35,1 \\
\hline Prenj & 790 & 731 & 92,5 \\
\hline Sjekose & 169 & 191 & 113,0 \\
\hline Svitava & 319 & 244 & 76,5 \\
\hline Višići & 1788 & 1855 & 103,7 \\
\hline TOTAL & 7882 & 7261 & 92,1 \\
\hline
\end{tabular}

Sources: Gelo et al., 1995; ANON., 2016)

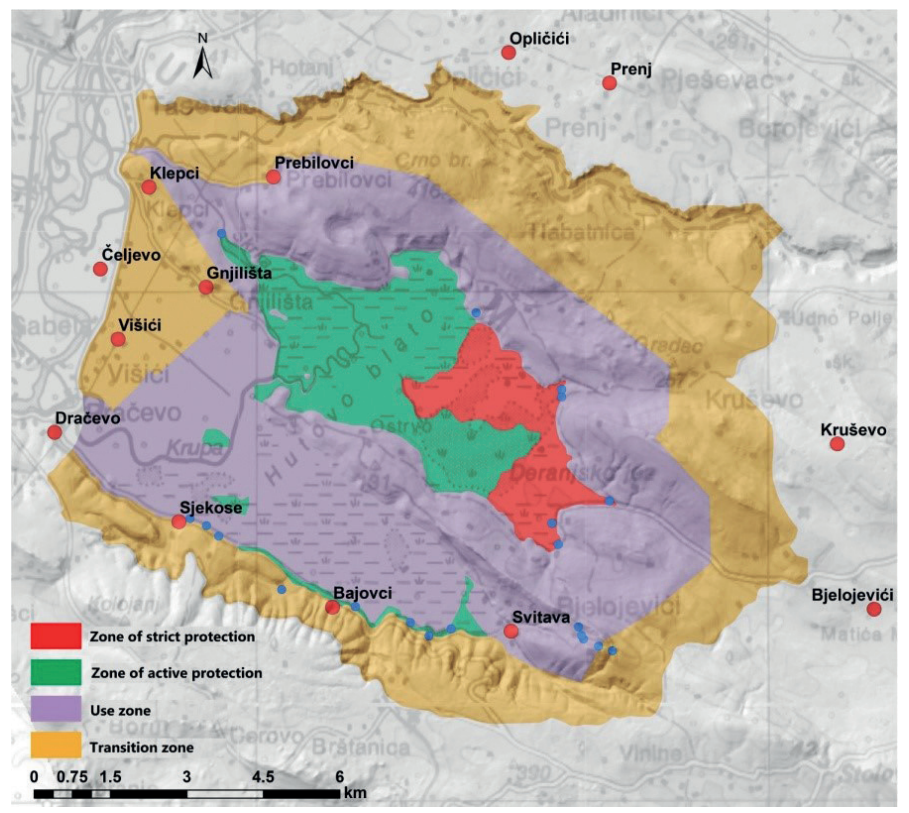

Fig. 3. Settlements in relation to the zoning of the Nature Park Hutovo blato

Unlike hunters, the local population is not institutionally organised and their actions against the official nature protection policy in Hutovo Blato are primarily individual. Besides conflicting with official nature protection laws, through their actions they challenge the Natural Park administration. Deeper analysis of internal structure shows that their stakeholder group is not strictly organised and is characterised with trade-offs regarding nature protection policy: there are individuals that are willing to accept such a policy if it benefits them economically. 


\section{Hydropower plant management as the third stakeholder}

The hydropower sector as a new stakeholder in the area of Hutovo Blato appeared in 1979 when a third of the area was flooded in order to form a reservoir. The reservoir was formed out of a small natural lake (Svitava Lake) that was greatly expanded. Environmental consequences were huge since a part of wetlands were flooded and ceased to exist. The plant uses the water on daily basis according to its own needs, completely disregarding the environmental impact. In addition, in 2019 the regional electric company of West Herzegovina that owns the plant signed a production and distribution of electricity contract with the regional authorities of East Herzegovina. The agreement resulted in a worsening of the water regime in Hutovo Blato since the water inflow from the karstic area of East Herzegovina is now 25 times higher (from 5 to 75 cubic metres per second $\left.{ }^{* * * *}\right)$. Such a water distribution results in high waters in Hutovo Blato even during the summer droughts.

The hydropower sector is the most powerful stakeholder in Hutovo Blato from the point of view of environmental repercussions. Besides changes of landscape its water management influences the plant and animal species that live in the wetlands just like the tourism development in the Park. Their point of view of the current conflict is to disrespect any kind of nature protection policy that conflicts with their activity - energy production. In addition, they often play down or neglect the environmental issues that they are responsible for. The current position of the hydropower stakeholder group is strong since electricity production is one of the most important activities in Bosnia and Herzegovina of export significance. This stakeholder group in Hutovo Blato is backed by a powerful corporation that dominates electricity production and supply in the southwestern part of the country. At the present moment they do not show any will to cooperate on the issues of sustainable management of natural resources in Hutovo Blato.

\section{The Nature Park administration as the fourth stakeholder}

Institutionalisation of the nature protection policy - which started 25 years ago - has thrown another stakeholder into the picture: ever since then, in accordance with its legal authorities, the Nature Park administration has been trying to implement the official nature protection and conservation laws. In pursuit of that goal, the Nature Park administration is trying to fulfil the legislative framework while not opposing the other stakeholders' activities. However, maintaining such a direction did in fact mean getting into conflict with other stakeholders.

The Nature Park officials even understand the need to produce the electricity while trying to find a common language with the hydropower plant in Hutovo Blato that would be to everyone's benefit. Still, implementation of the statutory policy has proved questionable from the point of other stakeholders. Even the tourism sector is not satisfied since they were expecting faster tourism development that would be to their advantage. While trying to implement the nature protection regulations and comply with the laws on one hand and achieve a higher level of tourism development on the other, the Park administration is attempting to justify its purpose. They are trying to achieve their goals inside the prescribed legal framework that at the same time defines the

\footnotetext{
**** An unofficial estimation of the Nature Park administration goes as high as 150 cubic metres per second.
} 
limitations to their actions. It is very hard to believe that such a goal can be achieved without effective back-up from the national and regional governments: current downsizing in number of the Park's personnel is not in favour of its realisation.

\section{Tourism sector as the most recent stakeholder}

The fifth stakeholder group appeared recently at the turn of the century after the Nature Park was established. It consists of renters of apartments and weekend houses that rightly see the opportunity of tourism development as a new source of income. Members of this group see their chance in the proximity of southern part of Croatia that is one of the most developed tourism regions in the neighbouring country. In addition, the Nature Park is situated at the key traffic corridor that connects the southern and central part of southernmost Croatian region of Dalmatia with the historic towns of Počitelj and Mostar and the pilgrimage centre of Međugorje in Herzegovina. The only littoral destination of Bosnia and Herzegovina, the town of Neum, is also inside the range of half an hour's drive. Nevertheless, current results of tourism development are still very low and unsatisfactory.

This stakeholder group is not very active in promoting its goals. Instead, they are relying on actions of tourism agencies, Nature Park administration and tourism boards that will, it is hoped, result in the faster tourism development of the area.

\section{Nature management conflict with specific patterns of inter-action and de- pendence}

The five stakeholders whose activities and attitudes regarding nature protection and conservation are described below (Tab. 3) operate in circumstances that are determined by current economic, political and social realities. Their attitudes and points of view concerning the policy of nature protection and conservation generate the problems that burden the functioning of the Nature Park.

Tab. 3. Stakeholders, their activities and their points of view nature of resource management in Nature Park Hutovo blato

\begin{tabular}{|l|l|l|}
\hline STAKEHOLDERS & ACTIVITIES & POINTS OF VIEW \\
\hline $\begin{array}{l}\text { Nature Park } \\
\text { administration }\end{array}$ & $\begin{array}{l}\text { nature } \\
\text { protection }\end{array}$ & $\begin{array}{l}\text { nature protection as part of state policy, restriction or } \\
\text { prohibition of all activities that damage the environment, } \\
\text { development of sustainable activities with a reliance on } \\
\text { tourism }\end{array}$ \\
\hline Hydropower sector & $\begin{array}{l}\text { water resources } \\
\text { exploitation }\end{array}$ & $\begin{array}{l}\text { exploitation of water resources at all costs, electricity } \\
\text { production as an extremely important activity, environmen- } \\
\text { tal consequences irrelevant, profit crucial, protecting jobs }\end{array}$ \\
\hline Hunters/fishermen & hunting/fishing & $\begin{array}{l}\text { the use of the animal stocks while adhering to the policy of } \\
\text { hunting clubs, denying the Park's authority, poaching }\end{array}$ \\
\hline Tourism sector & renting & $\begin{array}{l}\text { maintaining their lifestyle and activities, using natural } \\
\text { resources in traditional contexts, denying the Park's } \\
\text { authority in the event of a conflict between nature protection } \\
\text { policy and their activities }\end{array}$ \\
\hline $\begin{array}{l}\text { tourism as the future of settlements within and along the } \\
\text { borders of the Park, unimpeded construction of tourism } \\
\text { facilities, increasing the attractiveness of the Park for tourists } \\
\text { (arrangement of infrastructure, organisation of activities) }\end{array}$ \\
\hline
\end{tabular}


We can start with asking the question: where did it all begin? Although nature protection and conservation policy existed before the Nature Park was established, the stakeholders who are against it blame the Nature Park administration for the ongoing conflict. The advocates of such a point of view (the first three stakeholders) defend their position with well-known facts: from the first forms of formal protection in 1954 (ornithological reserve) and in 1959 (strict reserve of Štrka) all the way to 1971 (inclusion on the list of Ramsar sites) and 1980 (international project for Mediterranean wetlands protection) there was no conflict among the stakeholders. So, from their point of view the conflict started in 1995 when the Nature Park was established, and the Park administration appeared as a new stakeholder. It is true that there was no conflict before just as it is true that the nature protection policy existed only on paper but was totally inefficient without any real monitoring and control. When considered the two facts it is obvious that establishing the Nature Park brought a new dimension to nature protection in Hutovo Blato.

Putting aside the stakeholders' opinions on the problem of nature protection, we can analyse some basic facts of the problem. The first one is the way that the Nature Park was established applying top-down conservation without previous talks with possible stakeholders in Hutovo Blato. It is a type of conservation that has by now given limited results in nature conservation and management around the world. However, it is still the only approach that is applied in Bosnia and Herzegovina. Although the war circumstances in which the Park was established should be considered, one cannot escape the impression that the project could have been better designed.

The next question is why precisely Hutovo Blato was put in the Nature Park category that is - according to the applicable law - in category V of protected areas categorisation of the International Union for Conservation of Nature (IUCN). The very categorisation says that the very landscapes (or seascapes) that belong to the category should represent a balanced interaction between people and nature. It also says that such areas can sustain activities such as traditional agriculture and forestry under the condition that such activities ensure protection or restoration of the area (DUDLEY, 2008). Is there any other protection category that would better suit the wetlands of Hutovo Blato? That is a question that was not asked.

The next problem is the question that the three stakeholders who are not in favour of nature protection policy ask openly: what is at stake at all (Fig. 4)? This attitude is a product of undeveloped environmental consciences as well as of the economic realities in the area. The interviews showed that the three stakeholders, except for a part of the local population, do not question at all the accuracy of their understanding of the conflict. However, the majority of them do not know or appreciate the fact that the Park administration is underlining: two thirds of the original wetlands were destroyed in the second half of the $20^{\text {th }}$ century (one third was reclaimed and transformed into agricultural land and another third was flooded by the hydropower plant). When confronted with this reality and the basic facts about Mediterranean wetlands the three stakeholder groups who oppose the nature protection policy do show a certain change in their attitude. What remains unchanged is their view of the nature protection policy because it is in not offering any other development opportunities while at the same time, limiting the existing ones. Tourism development has not yet reached a significant level. Even the Park administration, which would like to see tourism as one of the main activities in Hutovo Blato, is not satisfied with current results. 


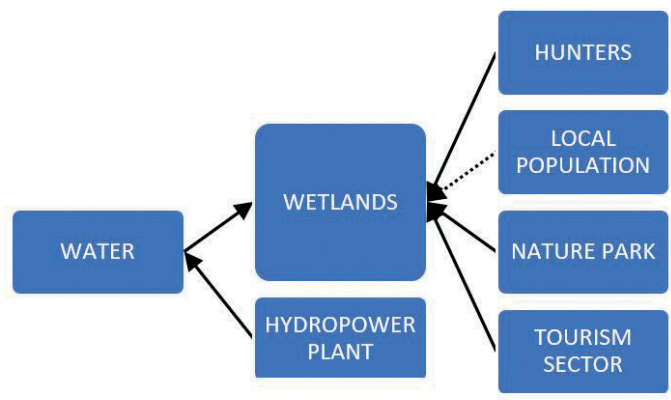

Fig. 4. Stakeholders and their dependence on natural resources in Hutovo blato Nature Park of (solid line signifies strong dependence and the dotted line mild dependence)

There is one more thing that should not be overlooked and it concerns the institutional frame of the conflict in the excessively politicised setting of Bosnia and Herzegovina. According to the applicable laws nature parks are under the jurisdiction of the government of the Federation of Bosnia and Herzegovina with its seat in Sarajevo. That fact is often used as an argument by the stakeholders who oppose the protection since they see it as something that is forced upon them from the centre of power from which they feel alienated. The same argument is used in the conflict between the Park administration and the hydropower plant management since the plant is part of the regionally based company.

Legislative protection without considering possible participation of the local population in the process is an issue that still burdens the nature policy enforcement in the area. People whose everyday life and sometimes even existence depends on the local wetlands are good to have on your side especially in the case of nature protection and conservation policy. The interviews showed that it is necessary to better educate locals about the policy, just like the values of Hutovo Blato in wider context. There are some strong arguments that should be used like the uniqueness and rarity of Mediterranean wetlands, their importance for biodiversity and landscape and the fact that it is the last third of the original area.

In a situation with such a contrary attitude regarding the nature protection policy in Hutovo Blato, one question comes to mind: is there anything that unifies the stakeholders? And that is where tourism development comes as the answer (which does not include the hydropower plant). While the Park administration sees it as the most desirable sustainable activity with an educational component, the local population and renters see it as a possible source of income. Sustainable types of tourism such as bird watching and photo-safaris are also interesting to some of the hunters who are willing to participate as professional personnel.

Tourism development is often seen as the most important economic activity of protected areas both by locals just as by the observers. Beside marketing Hutovo Blato for tourists there is also wide unused space for researchers into wetland ecosystems from all around the world. Relying on tourism is fragile and vulnerable to economic and health crises. That is why other sustainable activities - such as traditional farming, various services and trades - should be supported in the quest to preserve the balance between people and nature. Such an approach needs detailed planning and rethinking with the support of local, regional, national and international institutions. 


\section{CONCLUSION}

Nature protection and conservation policy in Hutovo Blato is facing major challenges that make it difficult to carry out the Nature Park mission. A unique and rare ecosystem of Mediterranean wetlands is under threat and is likely gradually to disappear from the landscape just like many of the plants and animal species.

The results of this research have confirmed the first hypothesis that says that inadequate water resource management by the local hydropower plant presents the biggest threat to the nature protection and conservation policy. The very future of the Nature Park primarily depends of the plant's administration's willingness to cooperate on the subject.

The second hypothesis was also confirmed: beside hydropower sector there are other less visible stakeholder groups that equally challenge the nature protection and conservation policy. Alongside the plant's management and the Park administration, there are three more stakeholder groups: hunters, the local population and the tourism sector.

The authors of this research find it possible to respond in affirmative way to the third hypothesis that asserts that the current positions of stakeholder groups can be coordinated with a more comprehensive and better designed nature protection policy. However, the ongoing conflict is deeply rooted and the willingness of Nature Park administration to resolve it should be backed by both the national and regional governments as well as by international organisations. The agreement of all the stakeholders involved may be based on a participatory model that would rely on nature protection and conservation policy. It would be impossible to come to such an agreement without producing various development options for the people who use the wetlands resources. In addition to education about nature protection and the values and importance of wetlands, the realisation of development projects - from the fields of tourism, sustainable agriculture, trades and different services - is currently vital for the functioning of the Nature Park.

Received May 17, 2020

\section{REFERENCES}

Adeкola, O. \& Mitchell, G. 2011: The Niger Delta wetlands: threats to ecosystem services, their importance to dependent communities and possible management measures. International Journal of Biodiversity Science, Ecosystem Services \& Management 7(1), 50-68.

Aggestam, F., 2014: Wetland restoration and the involvement of stakeholders: an analysis based on value-perspectives. Landscape Research 39(6), 680-697.

Agrawal, A., 1995: Indigenous and scientific knowledge: some critical comments. Indigenous Knowledge and Development Monitor 3(3), 3-6.

Ajmal Hussan, J. K., Sundaray, R. N., Mandal, F. H., Arabinda Das, P. P. C. \& Adhikari S., 2019: Invasion of non-indigenous suckermouth armoured catfish of the genus Pterygoplichthys (Loricariidae) in the East Kolkata Wetlands: stakeholders' perception. Indian J. Fish 66(2), 29-42.

Armenia, S., Bellomo, D., Medaglia, C. M., Nonino, F. \& Pompei, A., 2019: Water resource management through systemic approach: The case of Lake Bracciano. Journal of Simulation, DOI: 10.1080/17477778.2019.1664266

Attlee, A. C., Reed, M. S., Carter, C. E., Scott, A. J., Vella, S., Hardman, M. \& Neumann, R. K., 2015 : Looking to the future of ecosystem services - areview of available approaches tools for assessing ecosystem services futures: a review. CAB reviews: perspectives in agriculture, veterinary science, nutrition and natural resources 10(024), 1-13. 
Buijs, A., Hovardas, T., Figari, H., Castro, P., Devine-Wright, P., Fischer, A., Mouro, C. \& Selge, S., 2012: Understanding people's ideas on natural resource management: research on social representations of nature. Society \& Natural Resources 25(11), 1167-1181.

Christie, P., 2004: Marine protected areas as biological successes and social failures in Southeast Asia. American Fisheries Society Symposium 42, 155-164.

Cohen-Shacham, E., Dayan, T., de Groot, R., Beltrame, C., Guillet, F. \& Feitelson, E., 2015: Using the ecosystem services concept to analyse stakeholder involvement in wetland management. Wetlands ecology and management 23(2), 241-256.

Cullen, B., Tucker, J., Snyder, K., Lema, Z. \& Duncan, A., 2014: An analysis of power dynamics within innovation platforms for natural resource management. Innovation and Development 4(2), 259-275.

De Vente, J., Reed, M. S., Stringer, L. C., Valente, S. \& Newig, J., 2016: How does the context and design of participatory decision making processes affect their outcomes? Evidence from sustainable land management in global drylands. Ecology and society 21(2), 24.

Dixon, A. \& CARrie, R., 2016: Creating local institutional arrangements for sustainable wetland socio-ecological systems:lessons from the 'Striking a Balance' project in Malawi. International journal of sustainable development \& world ecology 23(1), 40-52.

Dudley, N. (ED.), 2008: Guidelines for Applying Protected Area Management Categories. International Union for Conservation of Nature, Gland, $86 \mathrm{pp}$.

ENSERINK, B., 2000: A quick scan for infrastructure planning: screening alternatives through interactive stakeholder analysis. Impact assessment and project appraisal 18(1), 15-22.

Evely, A. C., Pinard, M., Lambin, X., Reed, M., S. \& Fazey, I., 2011: High levels of participation in conservation projects enhance learning. Conservation letters 4, 116-126.

Everard, M., Kangabam, R., Timari, M. K., McInnes, R., Kumar, R., Talukdar, G. H., Dixon, H., Joshi, P., Allan, R., Joshi, D. \& DAs, L., 2019: Ecosystem service assessment of selected wetlands of Kolkata and the Indian Gangetic Delta: multi-beneficial systems under differentiated management stress. Wetlands Ecology and management 27, 405-426.

FAJBER, E., 2005: Participatory research and development in nature resource management:towards social and gender equity. In: Gonsalves, J., Becker, T., Braun, A., Campilan, D., De Chavez, H., Fajber, E., Kapiriri, M., Rivaca-Caminade, J. \& Vernooy, R. (Eds.), Participatory research and development for sustainable agriculture and natural resource management - sourcebook, volume 1: understanding participatory research and development. International Potato Center-users' perspectives with agricultural research and development - International Development Research Centre, Laguna - Ottawa,51-57.

Fatorić, S., Morén-Alegret, R. \& Kasimis, C., 2014: Exploring climate change effects in Euro-Mediterranean protected coastal wetlands: the cases of Aiguamolls de l'Empordà, Spain and Kotychi-Strofylia, Greece. International Journal of Sustainable development \& World Ecology 21(4), 346-360.

Folmer, A., HaArtsen, T. \& Huigen, P. P. P., 2013: Explaining emotional attachment to a protected area by visitors' perceived importance of seeing wildlife, behavioral connections with nature, and sociodemographics. Human dimensions of wildlife: an international journal 18(6), 435-449.

Frooman, J., 1999: Stakeholder influence strategies. The Academy of Management review 24(2), 191-205.

German, L., Mazengia, W., Nyangas, S., Meliyo, J., Adimassu, Z., Bekele, B. \& Tirwomwe, W., 2012a: Participatory integrated watershed management. In: German, L., Mowo, J., Amede, T. \& Masuki, K. (Eds.), Integrated natural resource management in the highlands of eastern Africa: from concept to practice. Earthscan - International Development Research Centre, New York - Ottawa, 83-158.

German. L., Mazengia, W., Nyangas, S., Meliyo, J., Adimassu, Z., Bekele, B., Tirwomwe, W., 2012b: Participatory landscape governance. In: German, L., Mowo, J., Amede, T. \& Masuki, K. (Eds.), Integrated natural resource management in the highlands of eastern Africa: from concept to practice. Earthscan - International Development Research Centre, New York - Ottawa, 159-194.

Grimble, R., 1998: Stakeholder methodologies in natural resource management. Socioeconomic methodologies. Best practice guidelines. Natural Resources Institute, Chatham, 10 pp.

Grimble, R. \& Wellard, K., 1997: Stakeholder methodologies in natural resource management: a review of principles, contexts, experiences and opportunities. Agricultural systems 55(2), 173-193.

GuIJT, I., 1999: Participatory monitoring and evaluation for natural resource management and research. Socio-economic methodologies for natural resources research. Natural Resources Institute, Chatham, $20 \mathrm{pp}$.

Hamisi, H. I., Tumbo, M., Kalumanga, E. \& YAnda, P., 2012: Crisis in the wetlands: combined stresses in a changing climate - experience from Tanzania. Climate and development 4(1), 5-15. 
Has-SchöN, E., Bogut, I., Rajković, V., Bogut, S., Čaćić, M. \& Horvatić, J., 2008: Heavy Metal Distribution in Tissues of Six Fish Species Included in Human Diet, Inhabiting Freshwaters of the Nature Park "Hutovo blato" (Bosnia and Herzegovina). Archives of Environmental Contamination and Toxicology $54,75-83$.

Hulshof, M. \& Vos, J., 2016: Diverging realities: how framing, values and water management are interwoven in the Albufera de Valencia wetland in Spain. Water international41(1), 107-124.

Kourtis, I. M., Kotsifakis, K. G., Feloni, E. G. \& Baltas, E. A., 2019: Sustainable water resources management in small Greek islands under changing climate. Water 11(8), 1694, doi:10.3390/w11081694.

Lovrić, N., Lovrić, M. \& Martinić, I., 2011: Analysis of participatory processes in the formulation of spatial plan for Nature Park Medvednica. South-east European forestry 2(2), 61-71.

MAAn, J. S. \& Chaudhry, P., 2019: People and protected areas: some issues from India. Animal biodiversity and conservation 42(1), 79-90.

Magyera, K. \& GensKow, K., 2013: Toward integrated wetland conservation: a diagnostic framework. Journal of environmental planning and management 56(1), 121-139.

Marambanyika, T. \& Beckedahl, H., 2016: Wetland utilisation patterns in semi-arid communal areas of Zimbabwe between 1985 and 2013 and the associated benefits to livelihoods of the surrounding communities. Transactions of the Royal Society of South Africa71(2), 175-186.

Mitchell, R. K., Agle, B. R. \& Wood, D. J., 1997: Toward a theory of stakeholder identification and salience: defining the principle of who and what really counts. The Academy of Management review 22(4), 853-886.

Montoya Oliver, J. M. \& Mesón García, M., 1999: Ordenación de recursos naturales renovables: especies migratorias cinegéticas y piscícolas. Investigación agraria. Sistemas y recursosforestales8(1), 339-348.

Naskar, M., Roy, K., KarnataK, G., NAndy, S., K. \& Roy, A., 2017: Quantifying climate change induced threats to wetland fisheries: a stakeholder-driven approach. Environment, development and sustainability, doi: 10.1007/s10668-017-0018-6.

NASTRAN, M., 2014: Stakeholder analysis in a protected natural park: case study from Slovenia. Journal of environmental planning and management 57(9), 1359-1380.

Nsengimana, V., Weihler, S. \& Kaplin, B. A., 2017: Perceptions of local people on the use of Nyabarongo river wetland and its conservation in Rwanda. Society \& natural resources 30(1), 3-15.

Pendred, S., Fischer, A. \& Fischer, S., 2016: Improved management effectiveness of a marine protected area through prioritizing performance indicators. Coastal management 44(2), 93-115.

Peter, A., Mujuru, M. \& Dube, T., 2018: An assessment of land cover changes in a protected nature reserve and possible implications on water resources, South Africa. Physics and chemistry of the Earth 107, 86-91.

Prell, C., Hubacek, K. \& Reed, M., 2009: Stakeholder analysis and social network analysis in natural resource management. Society \& natural resources 22(6), 501-518.

Pristupa, A. O., Tysiachniouk, M., Mol A. P. J., Leemans, R., Minayeva, T. \& Markina, A., 2018: Can zoning resolve nature use conflicts? The case of the Numto Nature Park in the Russian Arctic. Journal of environmental planning and management 61(10), 1674-1700.

Probst, K. \& Hagmann, J., 2005: Participatory natural resource management research: a new integration domain in the agricultural sciences. In: Gonsalves, J., Becker, T., Braun, A., Campilan, D., De Chavez, H., Fajber, E., Kapiriri, M., Rivaca-Caminade, J., Vernooy, R. (Eds.), Participatory research and development for sustainable agriculture and natural resource management - sourcebook, volume 1: understanding participatory research and development. International Potato Center-users'perspectives with agricultural research and development - International Development Research Centre,Laguna - Ottawa, 203-211.

Qiu, J., Shen, Z., Chen, L., XIE, H., Sun, C. \& HuAng, Q., 2014: The stakeholder preference for best management practices in the Three Gorges Reservoir Region.Environmenal management 54(5), 1163-1174.

Reed, M. S., Bryce R. \& MAChen, R., 2018: Pathways to policy impact: a new approach for planning and evidencing research impact. Evidence \& policy 14, 431-458.

REED, M. S. \& CuRzon, R., 2015: Stakeholder mapping for the governance of biosecurity: a literature review. Journal of integrative environmental sciences 12(1), 15-38.

Reed, M. S., Stringer, L. C., Fazey, I., Evely, A. C. \& Kruijsen, J. H. J., 2014: Five principles for the practice of knowledge exchange in environmental management. Journal of environmental management 146, 337-345. 
Reed, M. S., Vella, S., Challies, E., de Vente, J., Frewer, L., Hohenwallner-Ries, D., Huber, T., Neumann, R. K., Oughton, E. A., Sidoli del Ceno, J. \& van Delden, H., 2018: A theory of participation: what makes stakeholder and public engagement in environmental management work? Restoration ecology 26, S7-S17.

Rıвот, J. C., 2016: Choosing representation: institutions and powers for decentralized natural resource management. In: Pierce Colfer, C. J., Capistrano, D. (Eds.), The politics of decentralization: forests, power and people. Routledge, Abingdon, 86-106.

Savage, G. T., Nix, T. W., Whitehead, C. J. \& Blair, J. D., 1991: Strategies for assessing and managing organizational stakeholders. Academy of management executive 5(2), 61-75.

Smith, M. J., Wagner, C., Wallace, K. J. \& Pourabdollah, A., 2016: Thecontributionofnaturetopeople: applyingconceptsofvaluesandpropertiestoratethe management importance of natural elements. Journal of Environmental Management175, 76-86.

Tanui, J., Sanginga, P., German. L., Masuki, K., Mansoor, H. \& Ayele, S., 2012: District institutional and policy innovations. In: German, L., Mowo, J., Amede, T., Masuki, K. (Eds.), Integrated natural resource management in the highlands of eastern Africa: from concept to practice. Earthscan - International Development Research Centre New York - Ottawa, 195-239.

Tutman, P., Glamuzina, B., Dulčıć, J. \& Zovko, N., 2012: IhtiofaunamočvareHutovo blato (donji tok rijekeNeretve, Bosna i Hercegovina); stanjeiugroženost. Croatian journal of fisheries 70(4), 169-185.

VAissière, A.-C., Levrel, H. \& PıосH, S., 2017: Wetland mitigation banking: negotiations with stakeholders in a zone of ecological-economic viability. Land use policy $\mathbf{6 9}, 512-518$

VArvasovszky, Z. \& Brugha, R., 2000: How to do (or not to do) ... a stakeholder analysis. Health policy and planning 15(3), 338-345

Verma, M. \& Negandhi, D., 2011: Valuing ecosystem services of wetlands - a tool for effective policy formulation and poverty alleviation. Hydrological sciences journal 56(8), 1622-1639

Vernooy, R., Ykhanabai, H., Bulgan, E., Beket, U. \& Graham, J., 2005: Challenges of participatory natural resource management research. In: Gonsalves, J., Becker, T., Braun, A., Campilan, D., De Chavez, H., Fajber, E., Kapiriri, M., Rivaca-Caminade, J., Vernooy, R. (Eds.),Participatory research and development for sustainable agriculture and natural resource management - sourcebook, volume 1: understanding participatory research and development. International Potato Center-users'perspectives with agricultural research and development - International Development Research Centre, Laguna - Ottawa, 220-227.

Wattage, P. \& Mardle, S., 2005: Stakeholder preferences towards conservation versus development for a wetland in Sri Lanka. Journal of environmental management 77, 122-132.

Zheng, D., Mi, J., Ravesteijn, W. \& QIU, F., 2014: Responsible resource management: the predicament and reform path for Chinese wetland conservation. Wetlands ecology and management 22, 509-521.

Additional sources

Anon., 2016: Popis stanovništva, domaćinstava i stanova u Bosni i Hercegovini, 2013. - rezultati popisa, Agencija za statistiku Bosne i Hercegovine, Sarajevo. (in Bosnian)

Gelo, J., Grizelj, M. \& Akrap, A., 1995: Stanovništvo Bosne i Hercegovine - narodni sastav po naseljima, Državni zavod za statistiku, Zagreb. (in Croatian) 
